Ancient Mesopotamia and Egypt

$$
\because
$$





\title{
Shifting Alignments: The Dichotomy of Benevolent and Malevolent Demons in Mesopotamia
}

\author{
Gina Konstantopoulos
}

When set against the more defined positions occupied by demons and monsters in other religions and cultures, the demons found in Mesopotamian texts may seem, at first glance, to exist in a perpetual state of disarray, defying attempts at a definitive categorization. ${ }^{1}$ Much of the time, these supernatural figures serve in malevolent positions, fulfilling their duties as carriers and causes of physical or mental illness, injury or disease. Despite this, demons may also fulfill benevolent roles, often coming to the aid of the exorcist, or āšipu, in his battle to remove a malevolent demon from the afflicted patient. From an initial, cursory analysis, we can easily see how demons may appear to shift from one role to another. Of the three demons, the udug, the lama, and the šedu, all of which switch from one category of acts-or one alignment, we could say - to another, the first two will form the focus of this study; as they are by far the most prevalent of the three to appear in Mesopotamian texts. ${ }^{2}$

In examining the potential angle of attack for a discussion concerning the fluid role of demons and other supernatural beings in Mesopotamia, the best approach may be a slightly circuitous one. Instead of approaching first and foremost the nature and character of the demons themselves, I would rather place them in the context of the texts wherein they appear. In treating the texts themselves, which occupy a number of different genres in Mesopotamia, from performative incantations to literary texts, as the narrative background for the demons, we see that the demons quickly appear less as independent agents

1 I am thankful to Piotr Michalowski, Gary Beckman, and Ellen Muehlberger for their comments on early drafts of this article.

This contrast is particularly seen if we consider J. Z. Smith's assertion that demons in antiquity, as well as cross-culturally, were presented as members of "so rigidly organized a realm" in order to be more effectively combated. J. Z. Smith, "Towards Interpreting Demonic Powers in Hellenistic and Roman Antiquity," in Aufstieg und Niedergang der Römischen Welt II.16.2, ed. Wolfgang Hasse (Berlin, 1978), pp. 437-438.

2 The šedu echoed the characteristics of the lama more than those of the udug and often appeared paired with the former when functioning benevolently, though it appears in a malevolent duo with the udug as well. 
than as characters occupying clearly defined roles: slotted into a very particular shape within a very particular section of each text's narrative.

If we stray further afield, we can find a useful framing for this argument in Vladimir Propp's work The Morphology of the Folktale, wherein according to Propp's analysis, the function of characters comprises a constant, unchanging element of the fairytale and exists independently of how and, more importantly for our purposes, by whom they are fulfilled. ${ }^{3}$ To fall back on old favorites, there is a slot within a text for a wolf and another for a woodsman, and the text requires that whoever occupies those roles appear when and where the text demands, and with the characteristics those roles demand, lest the entire structure of the narrative fall apart. In other words, the roles require actors, and while the identity of the actors themselves is important, it is superseded by the requirements of those roles themselves. In Mesopotamia, the narrative requirements of a literary text or an incantation dictate the alignment of the supernatural figures that fill it, without theological contortions on the part of the Mesopotamians, by all accounts. If a text requires that benevolent demons appear at one point, and malevolent demons at another, then that, more than any theological considerations of the nature of the demons themselves, dictates their actions and alignment within a certain point in the narrative of the text.

Mesopotamian incantations, a body of texts that stretched from the third millennium $\mathrm{BC}$ through to the end of the Neo-Babylonian period in the late first millennium, were, at their heart, performative texts, meant to create a definitive and measurable effect; whether by driving out the demon of illness within a patient and restoring him to health, or by acting apotropaically and protecting an individual or location from further and future harm. Despite the intended effective nature of these texts, they contained a structure similar to that of literary texts, with imbedded narratives that require a protagonist (most often the exorcist), with his assistants (helpful supernatural figures), and, of course, an antagonist (the malevolent supernatural figure or hostile witchcraft afflicting the patient). Incantations that focused on exorcism also followed a pattern known as the Marduk-Ea formula, and understanding the demons in the text requires a brief discussion on this topic.

3 Propp analysed one particular type of fairy tale, and the conventions he analysed held together well given the narrow range of that corpus. Similarly, the arguments concerning these figures in Mesopotamian texts are primarily limited to their appearances in incantation texts. Vladimir Propp, The Morphology of the Folktale, trans. Laurence Scott (Austin, 1968), p. 20. 
Within the Marduk-Ea incantation formula, the divine stand-in for the exorcist, Asalluhi (replaced, in later texts, by Marduk), examines the problem—or rather demon - afflicting the patient, and attempts to identify the exact cause of the illness. Asalluhi is invariably flummoxed in regards to both the identification of the problem and the potential treatment, and, lacking the knowledge to affect a solution, he consults with his father, Enki/Ea, the god of magic and incantations, concerning the misfortune, witchcraft, or demons afflicting the patient and summarily receives counsel and instructions on how to remove the affliction. Here, the exorcist remains the primary actor in this text, and Asalluhi is invoked early on as the child of Eridu, drawing on his link to the mystical pure-water source, the Apsu, which lies beneath the city, and on his father, Enki. ${ }^{4}$ The format of the incantation itself is strictly defined into rigid sections: the naming and enumerating of the evil demons afflicting the patient; Asalluhi's plea to his father and the instructions he receives from his father in response; and finally, Asalluhi (and thus the exorcist) carrying out those instructions to drive away the demons. These delineations created clear spaces in the text for benevolent and malevolent demons, respectively, to occupy. The benevolent demons appeared in the closing of the incantation, to aid the exorcist in his work, whereas the malevolent demons were listed in the opening of the text itself, as the forces afflicting the patient. ${ }^{5}$

The exorcist was not the only individual to combat demons in Mesopotamia. In fact, we see several different figures in Mesopotamia who dealt with illness and its supernatural causes, such as the $a s \hat{u}$, who was similar to a physician, and the mašmaššu, who operated primarily in the cultic setting. The supernatural figures known as the udug and the lama interacted predominantly with the $\bar{a}$ šipu. ${ }^{6}$ The business of the exorcist, most often the āšipu, was very much a

4 The Sumerian Marduk-Ea formula contains our most consistent use of a narrative structure in incantation texts, and thus it is no surprise that we see these irregular udug and lama figures in this type of incantation, where the narrative conventions can force them into an otherwise idiosyncratic service.

5 The Marduk-Ea formula was regular enough that even the particular grammar of each section of the text could be predicted: the exorcist receives instruction in the form of direct, second-person commands and is told of the expected results via the prospective once he has completed them. On this formula, see: Adam Falkenstein, Die Haupttypen der sumerischen Beschwörung, (Leipziger Semitistische Studien) 1 (Leipzig, 1968).

6 It should be noted, however, that these positions, particularly those of the āšipu and as were not always mutually exclusive from one another. Concerning the relationship between the two, see Nils P. Heeßel, "The Babylonian Physician Rabâ-ša-Marduk: Another Look at Physicians and Exorcists in the Ancient Near East," in Advances in Mesopotamian Medicine from Hammurabi to Hippocrates, ed. A. Attia and G. Buisson (Cuneiform Monographs) 37 
matter of combat in Mesopotamia. The demons that both embodied and acted as vectors for illness occupied a liminal space in Mesopotamian religious thought, and in order to combat them the exorcist found it necessary to place himself in the same liminal territory these demons occupied, opening himself up to the possibility of attack by the very demons he fought. The ensuing battle could be either implicitly or explicitly stated in the text of the incantation, and many incantations have a narrative quality that resembles the structure and plot found in myths and literary epics. The stage then set for the ǎsipu's epic struggles, the exorcist would have access to a number of tools to aid him in achieving victory, thus driving out the demon or witchcraft causing the affliction and so curing his patient. ${ }^{7}$

Incantation texts were a major weapon in the exorcist's arsenal. He also had access to divine favor in order to protect himself: first and foremost, the exorcist was viewed as acting in the stead and with the full authority of Enki, also known in Akkadian as Ea, the god of magic, who gave him the necessary power to combat demons. Added to this, the āšipu had the protection of his own personal god, a protective spirit attached specifically to him, who would protect him or appeal to the greater gods upon his behalf. In this same category of protective spirits, we see benevolent demons coming to the aid of the exorcist, being commanded to his service and protection. ${ }^{8}$ To confront a demon without these protections was dangerous at best and fatal at worst. Incantations are clear about the fate that awaits those who attempt it: in one instance, a man

(Leiden, 2009), pp. 13-28; E. K. Ritter, "Magical-expert (= āšipu) and Physician (=asû): Notes on Two Complementary Professions in Babylonian Medicine," in Studies in Honor of Benno Landsberger, ed. Hans G. Güterbock and Thorkild Jacobsen, (Assyriological Studies) 16 (Chicago, 1956), pp. 299-311 and JoAnn Scurlock, "Physician, Exorcist, Conjurer, Magician: A Tale of Two Healing Professionals," in Mesopotamian Magic: Textual, Historical, and Interpretative Perspectives, ed. Tzvi Abusch et al, Ancient Magic and Divination 1 (Leiden, 2000), pp. 69-79.

7 Demons served as both vectors of disease and as the actualized embodiment of a particular disease itself. One series of incantations detail the particular form of the demonic embodiment of a particular ailment known as Samana. On this disease and the group of incantations which combated it, see Irving Finkel, "A Study in Scarlet: Incantations against Samana," in Tikip Santakki Mala Mašmu: Eine Festschrift für Rykle Borger zu seinem 65 Geburtstag, ed. Stefan Maul, Cuneiform Monographs 10 (Leiden, 1998), pp. 71-106.

8 There are other, ancillary, figures that appear to aid the exorcist in his work, such as heroic figures more commonly found in literary texts, or natural forces. Our present focus is on the supernatural assistants themselves, however. For an overview of the different types of aid the exorcist could call upon: Cynthia Jean, "Male and Female Supernatural Assistants in Mesopotamian Magic," in Sex and Gender in the Ancient Near East (Helsinki, 2002), pp. $255^{-261 .}$ 
without the protection of a personal god confronts one demon, and in the process, the hapless, now vulnerable individual is attacked by other demons who carry him off to his presumably grisly fate. ${ }^{9}$ The protection afforded the exorcist by his personal god, as well as by the other benevolent spirits who aided him, was essential to his own continued well-being as the very act of exorcism exposed him to the same dangers that confronted his patient.

Given the important role of these figures, it is at first surprising that we see the same demon occupy different, and even opposing, roles. The good udug could, and did, aid the exorcist against the evil udug, even within the narrative space of a single text. Much of this dichotomy was, as discussed, a function of the nature and requirements of the texts themselves; however, having done my level best to open this study by robbing these supernatural figures of their agency as independent beings in Mesopotamian texts, we can see that these figures themselves are not without their own traits and tendencies.

In the full pandemonium of demons and monsters in Mesopotamia, we see that some are firmly set in their roles and rarely shift from their positions as benevolent or malevolent figures. ${ }^{10}$ Others, which form the focus of this study, could change allegiances based upon the roles they play—or the roles they are required to play-in incantations and literary texts. This mutable quality of these supernatural figures, or demons, was an integral aspect of their own composition, and is well represented in the two figures that are the focus of this study, the udug and lama. These two demons serve as the exorcist's assistants, his supernatural protection in incantations, but may also function as the very demons that threaten the patient the exorcist has come to cure. Their ability to switch from positive to negative roles within a text, however, is as much a function of the structure of the texts wherein they appear as it is a result of their own qualities. Before examining each figure in depth, it should be noted that the terms 'demon' and 'supernatural figure' which I use in this study are not perfect, and carry with them their own baggage that ill applies to how the figures of the udug and lama properly functioned within the context created by Mesopotamian texts. ${ }^{11}$

In this particular example, the "man who had no personal god" is not only possessed by the demons he was unable to defeat, but these demons also appear to assume his form entirely, killing the man and turning themselves into him. See: S. Lackenbacher, "Note sur l'Ardat-Lilî," Revue d'Assyriologie et d'Archéologie Orientale 65 (1971), pp. 395-401.

10 Frans Wiggermann, "The Mesopotamian Pandemonium: A Provisional Census," in Demoni Mesopotamici, ed. Lorenzo Verderame (Rome, 2011), pp. 298-322.

11 Where possible, both figures will be referred to primarily by their own native terminology, with a similar logic to the argument presented by Rangar Cline in his work on angels in 
Despite that, these supernatural figures exist attached to a history of enormous depth and complexity, and that, in turn, exerts its own influence on their actions within texts. Thus, we will engage in a brief discussion of the characteristics of the udug and the lama, before considering how the two figures work in tandem to both help and hinder the exorcist.

\section{The Udug}

The udug claims the dubious honor of being the most nebulous and ill-defined demon in Mesopotamia. ${ }^{12}$ As such, it is the most malleable figure that appears in incantations, capable of fitting into any number of different roles as the text requires. Particularly when set against other supernatural figures, such as the demon Lamashtu, ${ }^{13}$ who has both a clearly defined genealogy and an equally well-defined artistic representation, we see that there are few descriptions of the udug demon, and no pictorial references to it on either seal impressions or statuary. To further complicate matters, the word udug can itself apply to the specific demon, or be used to indicate the broad category of demonic entities

the Roman empire: "By maintaining the period-specific terminology I thus hope to avoid the imposition of an anachronistic terminological category. This approach is intended to more accurately reflect the religious views of the later Roman period rather than force such views to conform to religious and scholarly terminological categories of a later age, which would, by necessity, come laden with their own connotations and prejudices." Rangar Cline, Ancient Angels: Conceptualizing Angeloi in the Roman Empire, (Religions in the Graeco-Roman World) 172 (Leiden, 2011), pp. xv-xviii.

Note that udug is the Sumerian term for the demon; in Akkadian, the demon would be utukku.

13 Lamashtu, the daughter of the god Anu, was exiled from the company of the other gods thanks to her proclivity for the consumption of human flesh, particularly that of infants. Infant mortality is primarily attributed to her, and she is notably depicted as a monstrous female figure, lion-headed and eagle-taloned, suckling wild animals at her breasts. Lamashtu is a corrupted inversion of the concept of motherhood, and her attempts to fulfill a role (that of mother) for which she is not capable result in the death of infants. On Lamashtu, see: Frans Wiggermann, "Lamaštu, Daughter of Anu: a Profile," in Birth in Babylonia and the Bible: its Mediterranean Setting, ed. Martin Stol, Cuneiform Monographs 14 (Groningen, 2000), pp. 217-252. The incantations related to Lamashtu are newly edited and published, a volume which was forthcoming at the time of the writing: Walter Farber, Lamaštu: An Edition of the Canonical Series of Lamaštu Incantations and Rituals and Related Texts from the Second and Third Millennia B.C., Mesopotamian Civilizations 17 (Winona Lake, 2014). 
in Mesopotamia. ${ }^{14}$ Even when it is an individual demon, as opposed to a collective term, the udug appears in a broad range of texts, both chronologically and geographically speaking, from the third millennium to the late first millennium. The closest approximation we have of a physical depiction of the demon comes from the prominent and broadly circulated standard Babylonian incantation series, Udug Hul or Utukkū Lemnūtu, "Evil Demons," wherein the udug is one of the many evils threatening mankind. In one text-part of a larger bilingual Sumerian and Akkadian series of incantations which also features, seen in the section quoted below, the Marduk-Ea formula-the god Asalluhi describes the demon to his father, Enki/Ea, in the following terms:

O my father, the evil udug (udug hul/utukku lemnu), its appearance is malignant and its stature towering,

Although it is not a god, its clamour is great and its radiance immense, It is dark, its shadow is pitch-black and there is no light within its body, It always hides, taking refuge, [it] does not stand proudly,

Its claws drip with bile, it leaves poison in its wake,

Its belt is not released, his arms enclose,

It fills the target of his anger with tears, in all the lands, [its] battle cry cannot be restrained..$^{15}$

As this text demonstrates, the udug is characterized by what it is not: the demon is nameless and formless, even in its early appearances. An Old Babylonian incantation featuring the udug identifies it as follows: "The one who, from the very beginning, was not called by name... the one who never appeared with a form."16 Its definition is given in negative. Even in the text quoted above, the udug's form is glossed over, and instead its terrifying abilities are highlighted. Attention is drawn to its shadow, the absence of light surrounding it, its poison, and the deafening power of its voice-all characteristics that are common among demons and monsters in Mesopotamia as a whole. This description, as tenuous as it already is, is made increasingly nebulous by the fact that it is not uniformly maintained across the sources, and depictions of the udug

\footnotetext{
14 Markham J. Geller, "The Faceless Udug-demon," in Demoni Mesopotamici, ed. Lorenzo Verderame (Rome, 2011), p. 333 .

15 Tablet 12: 13-20. Following the edition in Markham J. Geller, Evil Demons: Canonical Utukkū Lemnūtu Incantations, (State Archives of Assyria Cuneiform Texts) 5 (Helsinki, 2007).

16 See: Markham J. Geller, Forerunners to Udug-hul: Sumerian Exorcistic Incantations, (Freiburger Altorientalische Studien) 12 (Stuttgart, 1985), pp. 46-47.
} 
are subject to change in other texts wherein the demon appears. In the text above, its nature is clarified by the use of the adjective hul or 'evil,' though the adjective would not be required to inform the udug's nature in this malevolent instance, as we otherwise see the udug in its malevolent role without the adjective present.

This shifting quality of the udug demon and its inherent malleable quality arise, in part, from the flexibility of the term itself; as "udug" may refer to one demon or to a group of demons, when the udug appears as an individual demon, it is a study in generic description, a template for a perfectly average demon. We see it, for example, as an individual in one list of demons afflicting a patient: "An evil namtaru has seized his head, an evil utukku (udug hul/ utukku (eтпи) has seized his throat, an evil alû has seized his breast, an evil etemmu has seized his shoulders, an evil gallû has seized his hand, an evil god has seized his hand, an evil räbișu has seized his feet: they have covered this person like a net."17 Here, the udug is merely one demon among many, part of a great and vast legion, and none of the list are given any greater importance or significance when compared to the others. In this list of demonic figures we can also see a behaviour typical to Mesopotamian incantations: the incantation hopes to cover all possible demons that could threaten the afflicted, ensuring that no matter what the potential cause of the harm which has befallen the patient, it will be driven away. The epitome of this practice may well be the existence of the mimma lemnu, literally the "anything evil" demon, which was to be protected against and could occur at the end of a longer list of specific demons, to truly ensure that all potential threats were neutralized. ${ }^{18}$

The udug is the most widespread and frequently attested of all demons in Mesopotamia, although it is without any noted personality or character. It operates as a stand-in for demons as a whole in Mesopotamian texts, and is the closest term within the entire category of supernatural figures to denote a generic marker for demons. Even when it functions as an individual, its nature is ill defined. It often acts as a vector for illness, be it physical or mental, and acts thus in a persistently malevolent manner in incantations, a nature it tends to express even when simply written as udug/utukku instead of the full udug $\mathrm{hul} /$ utukku lemnu (evil udug). However, the demon is not exclusively malevolent, and also functions as an aid to the exorcist, a behaviour we will turn to after examining out next supernatural figure.

17 See E. E. Knudsen, "Two Nimrud Incantations of the Utukku Type," Iraq 27 (1965), 160-170.

18 JoAnn Scurlock, Magico-Medical Means of Treating Ghost-Induced Illnesses in Ancient Mesopotamia, (Ancient Magic and Divination) 3 (Leiden, 2005), p. 503. 


\section{The Lama}

As opposed to the ambiguous udug, the lama is clearly defined, at least in terms of its actions; with very few exceptions, the lama is a benevolent figure. ${ }^{19}$ Within incantations, the lama stands alongside the exorcist and provides both protection and support. Beyond that role, the lama has a long history of appearances within personal names, the earliest of which are dated to the third millennium. ${ }^{20}$ In further contrast to the udug, the lama is most often depicted as a female figure, with a long history of being identified as a deity in Mesopotamia, although one with distinctly protective qualities, and as a protective spirit, associated with an individual or a specific place..$^{21}$ The oldest references to the lama come from Lagash, a city in southern Mesopotamia, which may suggest that this city is where the figure originated. ${ }^{22}$ Lagash itself possesses a religious tradition that, while connected to the broader traditions of Mesopotamia, retains its own unique aspects. The lama, however, quickly spread far beyond Lagash itself, to appear in texts from the broad sweep of Mesopotamia.

The oldest of these early Lagash texts is from the twenty-fourth century BC; the text itself is a list of riddles, formatted as a simple list of canals, each accompanied by the name of a fish and the name of a snake, and the reader is meant to identify the city from these details. Here, the lama appears as the city's patron deity and is thus responsible for its protection: "its canal is the Lama-igi bar, its deity is the good lama (dlama sa ${ }_{6}$-ga)." ${ }^{23}$ The writing of lama is also of importance: the lama is preceded by the determinative digirir, a classifier indicating divinity (attached to gods and occasionally kings) and

19 As with the udug/utukku, the figure claims the Sumerian term lama and the Akkadian term lamassu.

20 See: Robert A. DiVito, Studies in Third Millennium Sumerian and Akkadian Personal Names: the Designation and Conception of the Personal God, (Studia Pohl Series Maior) 16 (Rome, 1993).

21 Jean, "Male and Female Supernatural Assistants," 256.

22 Lagash was home to its own pantheon, which was attested from the earliest recorded periods of the city's history. See: Gebhard Selz, "Studies in Early Syncretism: the Development of the Pantheon in Lagaš, Examples for Inner-Sumerian Syncretism," Acta Sumerologica 12 (1990), 111-142; and Selz's longer monograph on the same subject: Untersuchungen zur Götterwelt des altsumerischen Stadtstaates von Lagaš, (Occasional Publications of the Samuel Noah Kramer Fund) 13 (Philadelphia, 1995). 
lama here is followed by the adjective "good," sa -ga. $^{24}$ The udug, particularly when it appears benevolently in texts, may also be written with this divine signifier preceding it. Although the lama is written with the divine determinative so often that attestations without it are unusual, even anomalous, the udug may be seen frequently with or without the digirir determinative.

Once the lama's role as a patron deity of a city, and thus responsible for its safekeeping, is established, we see an increasingly developed connection between the lama and protection in other texts in Mesopotamia, all of which reinforce this link between the protective power of the lama and its early role as a protective deity. In particular, the image of the lama as the protector and steward of cities is reinforced by the mention of specific temples that were built and dedicated to the lama in this early period of the late third millennium вс. ${ }^{25}$

From these first attestations as an individual goddess, one who was tasked with the protection and patronage of a particular city, the lama slowly develops an identity as a protective spirit who can serve other deities but is not always an independent goddess in her own right. While this pattern began to develop in these early attestations from the city of Lagash, it is also present later, seen in an Old Babylonian text where the lama appears as a spirit who is subservient to the goddess Baba. Although the lama in this text is not described as 'good,' its function is clearly benevolent. ${ }^{26}$ Once again, the inclusion of the adjective is not required to inform or clarify the lama's intentions within the text: even without it, the lama can function benevolently. From here on, we see the lama developed as a protective figure that may be attached to an individual as easily as to a city, and whose removal or departure would cause that person harm or ill fortune. Texts known as city laments, which describe the destruction of urban centers, use the abandonment of a city by its protective spirits, one of which is the lama, as one of the final signs before the city's complete and total destruction: "[the city's] lama ran away; its lama (said) 'hide in the steppe!'; [it] took unfamiliar paths." 27 In this text, the lama removes itself not only from the city, but also from civilization entirely, retreating to the steppe or desert, the eden, a liminal area that is more often associated with monsters and demons.

24 Determinatives are written in superscript preceding a word, and often abbreviated in modern transcriptions. The digiir, the only determinative that concerns us, is written simply as a superscript letter "d." Thus, the dlama sa ${ }_{6}$ ga would, as a term, parse to the divinized good lama.

25 Dietz Otto Edzard, Royal Inscriptions of Mesopotamia: Early Periods (Toronto, 2008).

26 See Åke W. Sjöberg, “A Hymn to dLama-sa 6 -ga," Journal of Cuneiform Studies 26 (1974), 160.

27 M. W. Green, “The Uruk Lament," Journal of the American Oriental Society 104 (1984), 268. 
In this vein as a benevolent spirit, the lama is one of the supernatural figures that commonly serves as protection for the exorcist, aiding him in his work, and can also be attached to individuals in literary texts - a tradition which begins early, as seen when it appears in a Sumerian literary epic featuring the exploits of the hero and king Lugalbanda: "(Lugalbanda's) good udug ( ${ }^{\mathrm{d} u d u g} \mathrm{sa}_{6}$-ga) hovered before him; his benevolent lama (dlama sa ${ }_{6}$-ga) walked behind him." ${ }^{28}$ This text identifies the typical behaviour of protective spirits in Mesopotamia: to maintain a protected space around an individual, creating a space wherein no harm, be it of demonic origin or otherwise, can threaten whomever they are protecting. In incantations, their behavior is identical in that both udug and lama come to the aid of the exorcist. This furthermore leads us to one of the mutable qualities of the udug that serves as the next point to consider: although the udug is most closely associated with its demonic qualities, it can still act as a protective spirit, paired with the lama.

The lama is the product of its long history as a benevolent, apotropaic figure, first as a goddess in her own right, then as a protective spirit attached to a city or an individual. Moreover, the lama fulfills these roles in many different textual and artistic genres beyond incantations. As such, it is much more rooted in its role, and shifts into an antagonistic role only rarely, and only then in exceptional circumstances.

\section{Changing Loyalties: The Good Udug and Evil Lama}

Having established the general characteristics of both the udug and the lama, we turn now to the circumstances where they act against the expected pattern of said characteristics and behaviour; namely, when we see the udug appearing in a positive role, or the lama in a negative one. The udug, with its malleable character, takes to this change without too much trouble, and, despite its continued role as a malevolent figure, appears benevolently in literary texts, royal hymns, and incantations. The first category includes the literary text of Lugalbanda, as discussed above, but the incantations provide the most interesting examples of this ability. It should be noted, however, that both Lugalbanda stories employ the good udug as one of the king's protective spirits.

Of course, the attestations to the benevolent udug are vastly outnumbered by the number of times it appears in a malevolent role. In examining the texts wherein the good udug does appear, one pattern becomes immediately clear:

28 Herman Vanstiphout, Epics of the Sumerian Kings: the Matter of Aratta, (Writings from the Ancient World) 20 (Atlanta, 2003), p. 116. 
the ever-present pairing of the udug $\mathrm{sa}_{6}$-ga and the lama $\mathrm{sa}_{6}$-ga. When the benevolent udug does appear, it appears alongside the lama, allowing the latter to act as the exemplar by which the udug's behaviour is patterned. Although the udug appearing benevolently may be irregular, the pairing of a evil udug (udug hul) and good lama (lama sa $\mathrm{s}_{6}$-ga) would be unacceptable, particularly in light of the position of such a line within the incantation, where either two positive or two negative figures would be required.

The narrative of incantations falls into a very particular pattern when considering the aforementioned Marduk-Ea incantation formula, and even the incantations that do not visibly cite the markers of the Marduk-Ea formula may still mimic its structure, as seen in the incantation quoted below. This incantation, an exorcism against the demon Lamashtu, follows the conventions of structure and narrative that we would expect from an incantation conforming to the Marduk-Ea formula. We see the standard conventions of the formula within the text - the introduction of the affliction and list of evils causing it; Asalluhi questioning Enki/Ea on how to solve said affliction, and then receiving instructions that he then carries out to drive away the evil and heal the patient. In following along the Marduk-Ea pattern of the text, we come to the section wherein Asalluhi is given instructions, to alleviate the demonic presence, which is quoted in the excerpt below:

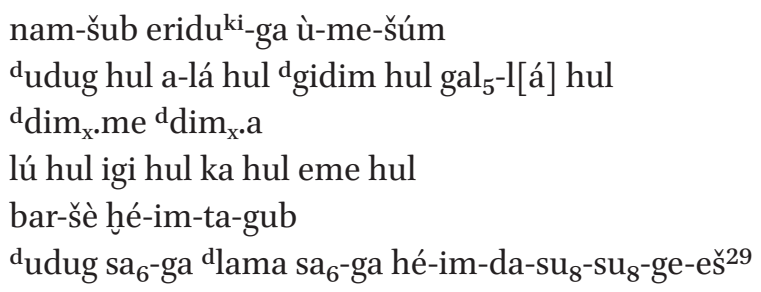

Once you cast the incantation of Eridu, The evil udug, evil ala, evil ghost, evil galla, Lamashtu, Labașu, Evil man, evil eye, evil mouth, evil tongueThey [all] will stand aside!

The benevolent udug and benevolent lama will stand attendant!

In the closing lines of the incantation, we have the key aspects of how the good udug (udug sa ${ }_{6}$-ga) and the evil udug (udug hul) interact. We see here that the

29 See M. V. Tonietti, "Un incantesimo sumerico contro la Lamaštu," Orientalia 48 (1979), 301-323. 
evil udug appears in proximity to the good udug, and both appear divinized, written with the divine marker, as do several of the other demons in the text. The close proximity of the two seems to pose no particular quandaries for the text or its audience.

Furthermore, the closing line of this incantation demonstrates another aspect of the udug's benevolence: when it does appear in this role, it appears in a set phrase. Thus it is even further distanced from any unique identifying characteristics, sparse though they may be when seen in conjunction with the evil attestations of the demon. That phrase, when appearing in incantations, follows the general pattern of the line quoted at the close of the incantation above, appearing as:

udug sa $\mathrm{sa}_{6}$-ga dlama sa ${ }_{6}$-ga hé-em-da-su ${ }_{8}$-su $_{8}$-ge-eš

The benevolent udug and benevolent lama will stand attendant!

While there is some variation possible with the particular Sumerian verbs in this line, the basic principle remains intact. The phrase appears close to the end of pertinent incantations, an assurance that the patient will be relieved from his sickness and returned to good health, and the supernatural figures of the udug and lama maintain a clearly delineated and protected space around the exorcist and the patient.

Conclusions concerning the udug are, in some regards, as tenuous as the demon itself. What is clear, however, is that the udug is inherently malicious, and even when the term is used to describe a group of demons, the demons within its purview are equally malevolent. The demon is a direct threat to mankind in the incantations wherein it appears, inflicting the harm that required the intervention of the ǎsipu. Its origins are not detailed in incantations, and it does not fall under the direct command of any major deity. Much like the term, the nature of the udug appears to be one of chaotic malignancy, and it appears benevolently only when paired with the lama.

\section{The Malevolent Lama}

Of the references to the lama, the overwhelming majority are positive, in which the figure serves a benevolent function, protecting the exorcist in incantations or standing as the protective spirit of a city or individual. Despite these tendencies, there are occasions where the lama appears in a malevolent, antagonistic context. There are three texts in particular that feature this behaviour, though, 
for our purposes, we will consider in greatest detail an Old Babylonian incantation against a demonized disease. ${ }^{30}$ In both of the other two texts, the lama hul appears together with the udug hul, and, moreover, it appears in this fashion in an appropriate place in the text's narrative; in one of the two texts, associated with Inanna, the evil udug and evil lama are associated with the temple of the steppe, the 'é-gal eden'. ${ }^{31}$ Though this section of the hymn is unfortunately fragmentary, the steppe would be more readily associated with malevolent supernatural figures than their benevolent counterparts. The other literary text, one dedicated to the goddess Ninisina and celebrating her healing qualities, presents the udug and evil lama in a section describing the various demons who had attacked a man, and thus their antagonistic nature is inevitable given their place in the text. ${ }^{32}$

The final text that details the dama hul is an Old Babylonian incantation, вм 92670, which-inclusion of the lama hul aside-follows a standard incantation format. The reverse contains a drawing of a demon, and the text appears matched, or perhaps one of a pair, to another incantation, Bм 92669. The two tablets share similar form and orthography, although they differ in content, as the latter is a difficult incantation dealing with the possible binding and removal of magic affecting the king through the scapegoat medium of a bird. Regardless, the text reinforces the underlying theory of forcing the afflictionbe it antagonistic magic or a malevolent demon - away from the patient. In вм 92669, the affliction is removed through the use of a scapegoat medium, and abstracted as something that may be manipulated and thus shifted from one location to another, and, in doing so, forced away from the afflicted. In the other text, cited below and treated in full in the appendix, the afflictions are conceptualized as a number of evil demons, including the dlama hul, and all are forced away from the patient to ensure his recovery:

30 The other two texts are both literary texts: a hymn to the goddess Ninegala and a hymn to the goddess Ninisina. Their respective editions are: Hermann Behrens, Die NinegalaHymne: die Wohnungnahme Inannas in Nippur in Altbabylonischer Zeit, (Freiburger altorientalische studien) 21 (Stuttgart, 1998) and Willem Römer, "Einige Beobachtungen zur Göttin Nini(n)sina auf Grund von Quellen der Ur III-Zeit und der altbabylonischen Periode," in Lišān mit [h]urti (Neukirchen-Vluyn, 1969), pp. 279-305.

31 Behrens, Die Ninegala-Hymne, pp. 58-59.

32 Römer, "Beobachtungen zur Göttin Nini(n)sina," p. 285: lines 45-57. 
BM 92670 Obv.

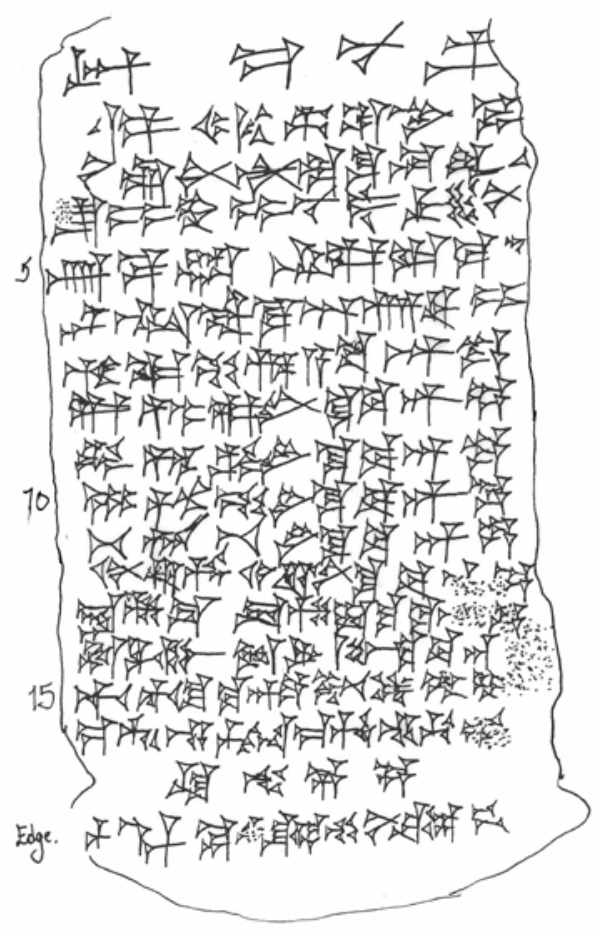

BM 92670 Rev.

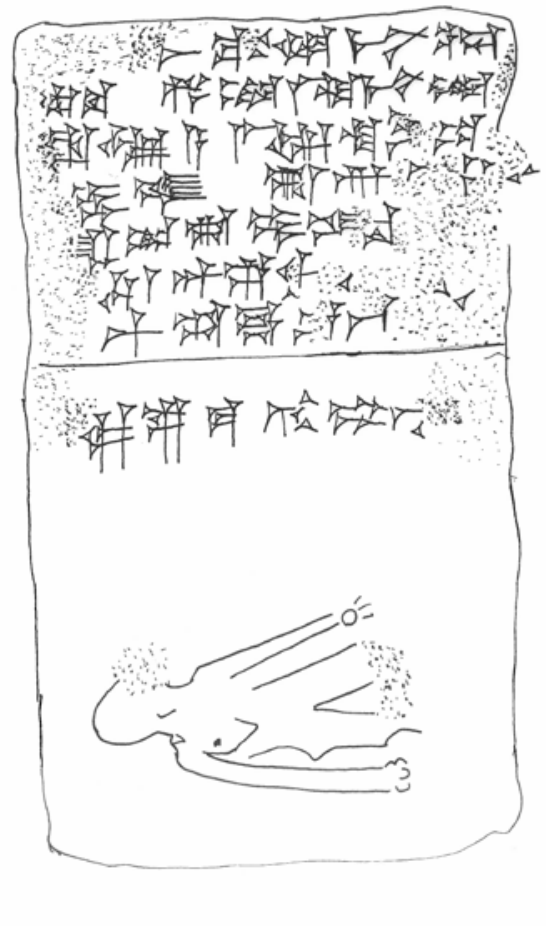

FIGURE 2.1

в м 92670: Reverse 1-6

1 xxx After you come forth,

2 After you burn away that poison by torch,

3 The evil ghost, evil ala demon from the body,

They will leave.

4 From the... they will leave

5 The evil udug, the evil lama-

They will stand aside!

6 This is the wording (of the incantation) of the substitute goat.

Given the overwhelming presence of the lama as a protective spirit, we must wonder why she is depicted as a malevolent spirit at all. The attestations of 
her in this context are scattered, and so it cannot be attributed to one scribal mistake or idiosyncrasy. These attestations give us evidence for the persistent malevolent presence of the lama in Mesopotamian texts.

In sum, the explanation for this behaviour lies in the pairing of the two figures and the narrative demands of the text. Just as the good udug takes its behavioural cues from the lama in texts where they appear benevolently together, to the point where the good udug is never found without the good lama in accompaniment, the lama here follows the lead of the normally malignant udug. In these few instances, the connection between the two figures and their constant repetition in texts as a paired set is a deliberate link to overcome the inherent tendency of the lama to be a positive figure. In either case, attestations where they appear against their normal natures are always marked with the appropriate adjective - the evil lama is always marked as the 'lama hul',

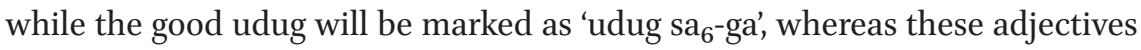
are not required when the figures are acting in accordance with their anticipated behavioural patterns.

In these examples we see evidence for the lama's potential to be malevolent, simply presented as an antagonistic figure that must be driven away by the āšipu, without apparent need for an explanation or theological contortions to explain the lama's unusual nature. When compiling the evidence for lama - the number of positive attestations, the presence of a benevolent nature even when unaccompanied by the adjective $\mathrm{sa}_{6}$-ga, the long history as a protective spirit and the attestations found in personal names, a clear case is made for the lama as a positive figure. Similarly, the udug - with its number of malevolent appearances, antagonistic actions in texts, associations with poison and bile, and frequent use of hul as an accompanying adjective-presents a clear and definite image as a malevolent supernatural entity in Mesopotamia. The overall ambivalence and fluidity in description of the udug allows for its more frequent appearances in a benevolent role, despite these malevolent roots.

\section{Conclusions}

The behavior of the udug and the lama are clearly deeply involved in the overall complexities of Mesopotamian incantations and the worldview that governed their creation and use. However, both figures can only be understood in light of their relationship with the textual tradition, and should not be interpreted as independent figures with fixed actions and natures. In laying the argument for why the udug and the lama behave as they do when they appear in texts, we have seen it break down into five major points: 
1) Mesopotamian incantations themselves have a strong central narrative that requires benevolent figures at one place and malevolent figures in another.

2) The figures - in this study, the udug or lama, though other supernatural figures are possible-must conform to that requirement when placed in that particular section of the narrative, which in turns works with the principle seen in the following point.

3) The connection between the udug and lama, along with the desire for symmetry, is strong enough that we do not see a pairing of evil udug and good lama, even if such a pairing were permissible within the text.

4) The lama has a strong and grounded tradition of operating as a benevolent figure, thanks to its long history as a goddess and then protective spirit in the Lagash region, while the udug has no such history and is, by its nature, an ill-defined and shifting demon.

5) Thanks to the above four points, a text is far more likely to pair the udug with the lama and shift them both into a benevolent role when a pair of figures is required. It is more peculiar for the lama to act against type, but the texts recognize that if the udug and lama are slotted into the role for a malevolent pair within the text, they must be cast as such, regardless of the lama's overwhelmingly benevolent nature, which may predispose but does not inhibit the lama from acting malevolently.

In other words, what we see within these texts is a strong predisposition for the lama and udug to act benevolently or malevolently, respectively. When they appear otherwise, it is against their respective predispositions but these actions are still permissible for each entity. In each case, that predisposition is overcome through the presentation of the oddly-natured demons as a pair. The symmetry of a good udug paired with a good lama — or an evil lama with an evil udug — seems to be the trigger for which role the entities will play, and this itself seems a function of context. The evil lama appears in a list of other evil demons, and the good udug in the proper place for a benevolent spirit within the incantation framework. In these few instances, the connection between the two figures whereby they operate as a pair, and the demands of their place within the narrative of the text, are deliberate links that overcome the inherent tendency of the lama and udug to appear as positive and negative figures, respectively.

\section{Appendix}

The following incantation, as discussed earlier, is one of a pair of two Old Babylonian incantations noted for the drawings of demons they display on the reverse of each 
tablet. BM 92670, edited in full below from my own collations of the tablet, contains one of the few definitive references to the lama hul, though the incantation itself is a fairly standard scapegoat ritual, wherein the affliction is removed from the patient and placed inside a substitute animal; in this particular case, a goat. The text, to date, has not been fully edited; though the tablet has been published in handcopy, ${ }^{33}$ the incantation itself has only been considered as one source for a created, composite incantation, and has not been edited as an independent text in its own right. ${ }^{34}$

BM 92670; CT 4426

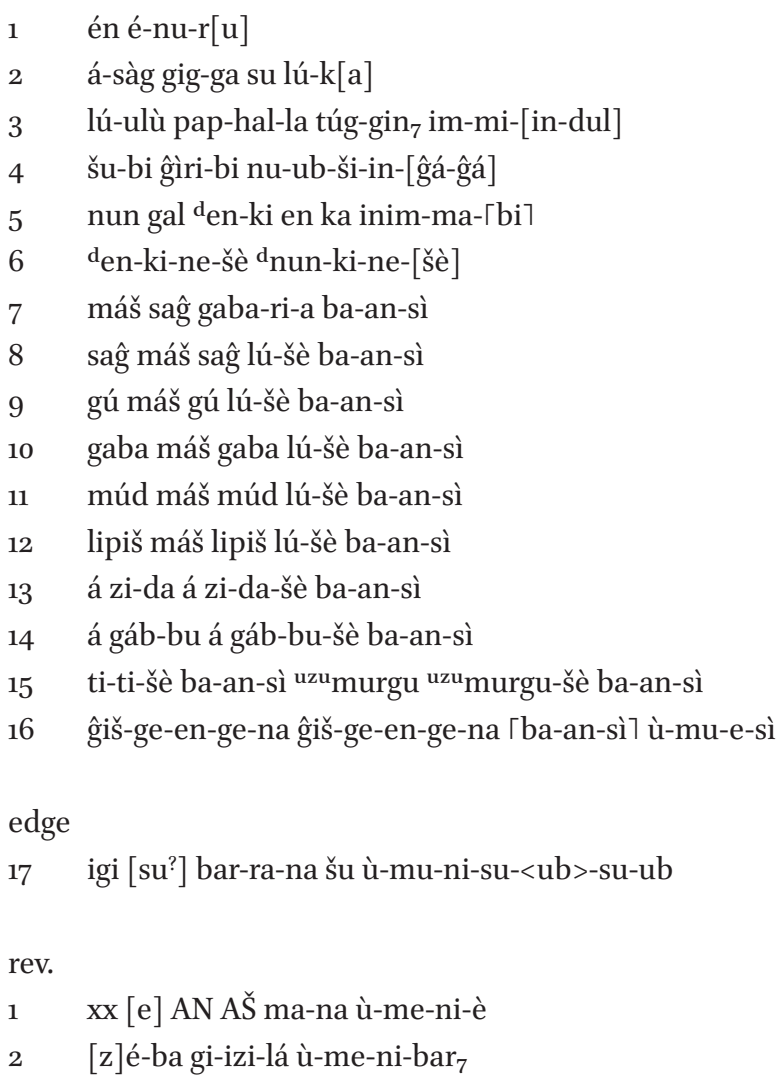

33 Th. G. Pinches, Cuneiform Texts from Babylonian Tablets in the British Museum, Vol. 44 (London, 1963).

34 Wolfgang Schramm, Ein Compendium sumerisch-akkadischer Beschwörungen, (Göttinger Beiträge zum Alten Oreint) 2 (Göttingen, 2008), pp. 40-43, 113-119. 
3 [gi]dim hul a-lá hul su-lú-ta hé-éb-ta-zil xxx-di ${ }^{35}$

4

$5 \quad$ [ ${ }^{\mathrm{d}}$ udug h]ul dlama h[ul]

bar-<ta hé-éb $>-d a-s u_{8}-s_{8}-g[e-e] \tilde{s}^{36}$

6 ka-inim-ma máš gaba-r[i-ga-kam]

1 Incantation:

2 The evil asag-demon is in a man's body,

3 It covers the patient like a garment,

4 He cannot raise his hand nor his foot,

5 The great prince Enki, this lord of incantations,

6 To the Enki and Ninki gods

7 He set a scapegoat as a substitute,

8 He set the head of the goat for the head of the man;

9 He set the neck of the goat for the neck of the man;

10 He set the chest of the goat for the chest of the man;

11 He set the blood of the goat for the blood of the man;

12 He set the innards of the goat for the innards of the man;

13 He set the right side [of the goat] for the right side [of the man];

14 He set the left side [of the goat] for the left side [of the man];

15 He set rib for rib; he set blood for blood;

$16\lceil$ He set 7 limbs to limbs. Once you have placed,

edge

17 The flesh he has seen; after you gather it together,

35 Schramm reconstructs this final verb as gu[ru]d; however, the tablet leaves space for at least one additional sign between the zil and di signs, and he cites no parallel incantations to compare against for this line and its reconstruction. We would expect a verb indicating that the evil ghost and ala demon are driven away from the body of the patient.

36 Concerning the reconstruction of this verb, the line we see on the tablet itself was most likely abbreviated out of concerns for space. The scribe has left considerable space for the figure drawn on the bottom of the reverse of this tablet (with a similar figure seen in an identical place on tablet Bм 92669) and presented an abbreviated form of the line to avoid needing to expand the text onto another line. We also see parallels in Bм $9266 \mathrm{~g}$ for the indented lines that comprise the second halves of lines three and five on the reverse of this text. An analysis of the broader and more complicated questions surrounding the drawing of the figure itself, as well as how this text may be considered alongside вм 92669 , is unfortunately beyond the scope of this present article. 
rev.

1 xxx After you come forth,

2 After you burn away that poison by torch,

3 The evil ghost, evil ala demon from the body,

They will leave.

4 From the... they will leave

5 The evil udug, the evil lama-

They will stand aside!

6 This is the wording (of the incantation) of the substitute goat. ${ }^{37}$

37 Concerning the substitute goat, or scapegoat, and its role in incantations, see: Antoine Cavigneaux, "Máš-Hul-Dúb-Ba," in Beitrage zur Kulturgeschichte Vorderasiens: Festschrift für Rainer Michael Boehmer (Mainz, 1983), pp. 53-67. 